\title{
СПОСОБЫ СОЗДАНИЯ САСПЕНСА В ПРОИЗВЕДЕНИЯХ ЖАНРА «ТРИЛЛЕР» НА АНГЛИЙСКОМ ЯЗЫКЕ
}

\section{Галганова Анастасия Анатольевна}

студент

Ишимский педагогический институт им. П.П. Ершова (филиал) ТюмГУ

Аннотация: Рассмотрены способы создания саспенса в произведениях жанра «триллер» на английском языке. Дано определение термину «саспенса». Оно определено как состояние, предполагающее возникновение у аудитории чувства тревоги и неопределенности. Определены способы создания саспенса в рассказе Стивена Кинга «1408».

Ключевые слова: саспенс, триллер.

\section{WAYS TO CREATE SUSPENSE IN THE WORKS OF THE GENRE "THRILLER" IN ENGLISH}

\section{Galganova Anastasia Anatolyevna}

\begin{abstract}
The methods of creating suspense in the works of the genre "thriller" in English are considered. The definition of the term "suspense"is given. It is defined as a state that implies a sense of anxiety and uncertainty in the audience. The ways of creating suspense in Stephen King's short story "1408"are defined.
\end{abstract}

Key words: suspense, thriller.

Понятие «саспенса» давно изучается. Автор словаря литературных терминов А.Ф. Скотт отмечает, что благодаря эффекту саспенса у читателя создается состояние «подвешенности», тревожного ожидания, на котором и играет автор. Сам термин мотивирован, так как происходит от латинского suspendere «подвешивать» [2, с. 281].

Жанр триллера не имеет четких границ, он может включать в себя элементы мистики, фантастики, шпионского боевика, политического детектива. Среди языковых приемов создания саспенса исследователи выделяют семантический повтор лексем с семами угрозы, беспокойства, 
неопределенности и др. Средствами создания саспенса могут быть ряд синтаксических конструкций. Свою роль могут играть стилистические приемы [1].

Стивен Кинг - американский писатель, создающий ужасы, триллеры, фантастику, фэнтези, мистические романы. Кинг часто пишет о писателях, он любит размышлять об опасностях писательского ремесла, главная из которых состоит в возможности проникновения созданного фантазией писателя мира в мир реальный. Эту идею Кинг успешно эксплуатирует в рассказе «1408». Рассказ описывает ночь, проведенную модным американским писателем, в комнате отеля, о которой ходят страшные слухи. Администрация отеля перестает сдавать этот номер, но писатель по имени Майк Энслин (Mike Enslin) настаивает на том, чтобы номер ему сдали. Он останавливается в комнате «1408» на одну ночь и сталкивается там с чем-то неизвестным.

В рассказе выделяется такой способ создания саспенса, как повтор лексики с семантикой страха. Кинг так как бы создает тот фон, на котором развивается сюжет произведения. Например: Olin was really afraid of room 1408, and of what might happen to Mike there tonight [3]; "You're telling me all this just to scare me, Mr. Olin, aren't you?" [3].

При этом интенсивность эмоции нарастает: так, когда Майк оказывает в комнате 1408, его охватывает уже не страх, а ужас (horror). Одновременно Кинг повторяет лексику с семой «зловещий». При описании комнаты 1408 Кинг всячески подчеркивает «нечеловеческий» характер того, что там обитает. Это осуществляется за счет использования слов something, whatever, thing. Кроме того, в рассказе повторяется группа слов, связанная с описанием негативных физических реакций героя. Он не может дышать, роняет вещи, его руки дрожат и т.д.

Свой вклад в создание саспенса вносят синтаксические средства. Так, в самых напряженных моментах предложения становятся короткими, эллиптическими. Парцеллированные, сегментированные и эллиптические предложения являются маркерами разрушения типичных форм связи между словами, это средства смысловой интенсификации текста.

Напряжение усиливает такой прием, как умолчание, когда предложение прерывается: Not that he felt that way himself, not at all, but -- [3]. В создании саспенса участвуют параллельные конструкции, лексический повтор.

Стилистические средства помогают Стивену Кингу дополнительно усилить уровень напряжения в рассказе. Сравнения, аналогии, метафоры с 
компонентами death, hell, ghost, grave усиливают негативное впечатление от комнаты 1408.

В процентном соотношении, наиболее частотны в рассказе синтаксические средства (54\%). Частью средств создания саспенса становится подбор лексики (26\%). Стилистические приемы занимают $20 \%$ от общего числа используемых писателем средств.

\section{Список литературы}

1. Жогова И.Г., Кузина Е.В., Медведева Л.Г., Надеждина Е.Ю. Языковые средства создания саспенса в произведениях жанра "триллер" и способы их актуализации (на материале романов англоязычных авторов) // Язык и культура. - 2018. - №2. - С. 183-188.

2. Scott A.F. Current Literary Terms. - Cambridge University Press, 1980. $324 \mathrm{p}$.

3. 1408 by Stephen King [Электронный pecypc]. - URL: http://www. silveraspen.net/1408.html (дата обращения: 27.05.2021).

(C) А.А. Галганова, 2021 